УДК 378.018.43:656.071.2-057(477)

Волошинов Сергій Анатолійович

кандидат педагогічних наук, доцент кафедри інноваційних технологій та технічних засобів судноводіння Херсонська державна морська академія, м. Херсон, Україна

ORCID ID 0000-0001-9127-9999

s_voloshinov@ukr.net

\title{
ЗАПРОВАДЖЕННЯ ЗМШШАНОГО НАВЧАННЯ У ПРОФЕСІЙНУ ПІДГОТОВКУ МАЙБУТНІХ ФАХІВЦІВ МОРСЬКОЇ ГАЛУЗІ
}

\begin{abstract}
Анотація. Автор актуалізує проблему запровадження змішаного навчання у професійну підготовку майбутніх фахівців морської галузі. На основі аналізу досліджень щодо застосування цифрових технологій у професійній підготовці майбутніх фахівців морської галузі зроблено висновок про те, що змішане навчання морських фахівців вимагає подальшого теоретичного осмислення та практичної реалізації. У статті здійснено опис практичного досвіду застосування змішаного навчання у освітньому процесі Херсонської державної морської академії (ХДМА). Зазначається, що компетентнісний підхід $\epsilon$ методичною основою змішаного навчання, адже метою професійної підготовки майбутніх фахівців морської галузі стають не набуття знань, умінь та навичок, а рівні досягнень ними компетентностей, тобто можливість здатності використання своїх знань, умінь та навичок у конкретній професійній ситуації. Подано напрями вдосконалення змішаного навчання у ХДМА. Зосереджено увагу на використанні LMS Moodle в організації асинхронного навчання майбутніх фахівців морської галузі. Запропоновано структурно-функціональну модель застосування змішаного навчання в професійній підготовці курсантів ХДМА. У ній акцентовано увагу на функціях структурних підрозділів ХДМА в організації та реалізації змішаного навчання, уточненні структури електронного курсу, функціях викладачів та інтерактивних засобах навчання. Подано приклад застосування можливостей 3D моделювання та сервісу LearningApps у навчанні англійської мови майбутніх фахівців морської галузі, а саме використання ігрових завдань «Вгадай слово», «Заповнити пропуски», «Кросворд», «Перегони», «Класифікація», «Знайди пару», «Просте упорядкування». Зазначено, що важливого значення для впровадження змішаного навчання набуває відповідна підготовка науково-педагогічних працівників та оволодіння ними цифровими компетентностями. Для цього в запропонованій моделі реалізовано підвищення кваліфікації викладацького складу в LMS Moodle шляхом навчання на електронних курсах.
\end{abstract}

Ключові слова: змішане навчання; професійна підготовка; морські фахівці; LMS Moodle, LearningApps.

\section{1. ВСТУП}

Постановка проблеми. Модернізація та реформування вищої морської освіти в Україні передбачає якісно новий підхід до іiі організації, що знаходить своє відображення в державних документах: «Морська доктрина України на період до 2035 року», «Стратегічний план розвитку морського транспорту на період до 2020 року», «Стратегія розвитку морських портів України на період до 2038», «Положення про державну систему управління безпекою судноплавства». Система підготовки та перепідготовки фахівців для морської галузі визнана морським потенціалом країни та умовою забезпечення безпеки судноплавства, а проведення морських наукових досліджень і підготовка та перепідготовка фахівців у морській галузі $\epsilon$ одним 3 пріоритетів національних інтересів України у сфері морської діяльності [1].

Протягом останнього десятиріччя в системі морської освіти України здійснюються заходи щодо інтеграції засобів інформаційно-комунікаційних технологій та науково-методичного забезпечення навчального процесу, спричинені прагненням 
України до формування Європейського простору вищої освіти. У Паризькому комюніке (2018) [2] щодо подальшого просування запровадження Свропейського простору вищої освіти зазначено, що заклади вищої освіти мають готувати студентів і підтримувати викладачів так, щоб вони діяли творчо в цифровому середовищі, а також надавати можливість краще використовувати цифрову та змішану освіту 3 відповідним забезпеченням якості, щоб покращити навчання впродовж життя та гнучке навчання, плекати цифрові навички та компетентності, удосконалювати аналіз даних, освітні дослідження та прогнозування й усунути регуляторні перешкоди щодо надання відкритої та цифрової освіти.

Ця тенденція спричиняє підвищення вимог до професійних якостей майбутніх фахівців морської галузі. Через те, що технології та знання невпинно оновлюються, підготовка фахівців морських спеціальностей має забезпечувати не тільки фахові знання, а й формування здатності до самоорганізованого та самокерованого навчання, бажання навчатися протягом життя, уміння соціально взаємодіяти 3 використанням сучасних інформаційно-комунікаційних технологій (ІКТ).

Аналіз останніх досліджень і публікацій. Питання інформатизації освіти висвітлюють у наукових працях Ван Б. (Wang В.), Сінг Х. (Xing Н.), В.Ю.Биков, В.П.Вембер, А.М. Гуржій, В.В.Осадчий, А.Ю.Пилипчук, Ю.С. Рамський та ін.. Ван Б. та Сінг Х. наголошують, що для розвитку інформаційних технологій в освіті важливе значення мають хмарні обчислення, які відіграють важливу роль у створенні гнучкої, уніфікованої та відкритої платформи обміну навчальними ресурсами та полегшення інформаційного обміну [3]. Слушно зазначає В.Ю.Биков, що інформатизація освіти передбачає і каталізує загальні процеси розвитку суспільства й освіти, водночас суттєвих специфічних рис набувають основні складові систем навчання, виховання i освіти: зміст освіти, методи, засоби та технології навчання і виховання, організація систем навчання і освіти, головні ресурси цих систем: інформаційні, матеріальнотехнічні та енергетичні [4]. А.Ю.Пилипчук наголошує, що інформатизація освіти визнана одним із пріоритетних державних завдань та повинна бути невід'ємною складовою інформатизації України і здійснюватися згідно 3 єдиними державними нормативами, враховуючи при цьому особливості системи освіти [5]. В. В. Осадчий та К.П. Осадча виділяють такі світові тенденції розвитку інформаційних технологій в освіті: розуміння IКТ-компетентності як засобу отримання всіх інших компетентностей для навчання протягом життя; забезпечення рівного доступу до комп'ютерної техніки й інформації в Інтернеті всім верствам населення; орієнтація на вільний доступ кожного члена суспільства до інформаційних ресурсів мережі Інтернет та участі кожного в інформаційному суспільстві; створення інформаційного суспільства, в якому поважаються людська гідність, свобода та права людини; використання інформаційних і комунікаційних технологій на благо людей; розвиток дистанційного, віртуального або доповненого типу навчання; впровадження системи оцінювання стану інформатизації навчального закладу; впровадження глобальної культури кібербезпеки; реалізація за допомогою ІКТ-безперервної освіти та освіти для дорослих, професійної перепідготовки, навчання протягом усього життя [6, с. 53]. Ці тенденції спонукають до модернізації професійної підготовки морських фахівців 3 використанням сучасних інформаційних технологій, серед яких виділяються дистанційні та змішані технології.

Питання впровадження дистанційних технологій у процес професійної підготовки висвітлювали В.В. Олійник, Т.І. Коваль, С.М. Смирнова-Трибульска, П.В. Стефаненко та ін., зокрема теорію і практику змішаного навчання досліджували К.Л. Бугайчук, В.М. Кухаренко, О.О. Рафальська, Н.В. Рашевська, Б.І. Шуневич та ін.. Т.І. Коваль визначає такі цілі впровадження дистанційних технологій навчання у професійну підготовку майбутніх фахівців: формування кожного студента як суб'єкта учіння; 
становлення рефлексивних умінь і навичок студентів у процесі професійної підготовки; посилення навчальної мотивації і становлення особистості, здатної до адаптації щодо нових соціально-економічних умов ринку праці; стимулювання інтелектуальної активності студентів, становлення гуманної, творчої, активної, відповідальної та ініціативної особистості; всебічний розвиток студентів з урахуванням їхніх навчальних досягнень, можливостей і здібностей кожного, організація навчання за індивідуальною траєкторією учіння [7].

Слушно зазначає В.В. Олійник, що мережева технологія дистанційного навчання - це основна педагогічна технологія освіти XXI ст., адже вона має великі потенційні можливості, а змішані технології дистанційного навчання передбачають обгрунтоване й органічне поєднання елементів різних технологій в єдине ціле і їх застосування в навчанні можна розглядати як етап переходу від технологій нижчого порядку до вищого [8, с. 50]. К.Л. Бугайчук виділив такі ознаки змішаного навчання: змішане навчання належить до формального навчання в рамках діяльності освітніх установ; це цілеспрямований процес здобуття знань, умінь та навичок у рамках певних навчальних дисциплін, частина якого реалізується у віддаленому режимі; під час вивчення навчальної дисципліни використовуються ІКТ та ТЗО (ПК, мобільні телефони, планшети, проектори тощо); IКТ використовуються не тільки для зберігання і доставки навчального матеріалу, але й для реалізації контрольних заходів, організації навчальної взаємодії (консультацій, обговорення); має місце самоконтроль учня (студента) за часом, місцем, маршрутами та темпом навчання [9].

У професійній педагогіці питання організації професійної підготовки майбутніх фахівців морської галузі досліджували С.Л. Барсук, Л.Д. Герганов, С.В. Козак, Н.М. Пріміна, В.В.Чернявський та ін. Впровадження ІКТ у процес професійної підготовки фахівців морської галузі досліджували А.Б.Андрійчук, О.М. Гудирева, О.О.Доброштан, В.M. Кліндухова, зокрема використання STEM-технологій розглянуто I.В. Богомоловою, а технологій дистанційного навчання - Г.Ю. Васильченком, Л.В. Кравцовою, Н.Г. Камінською, В.В.Чернявським. Однак слід підкреслити, що основна увага в проаналізованих дослідженнях приділяється теоретичним та практичним аспектам навчання окремим дисциплінам (фізика, математика, механіка) та формуванню комунікативної компетентності майбутніх морських фахівців. Питання застосування інформаційно-комунікаційних технологій, зокрема дистанційних, в освітньому процесі морської академії вимагають додаткового дослідження.

Мета статті. Визначити шляхи застосування змішаного навчання в професійній підготовці майбутніх фахівців морської галузі на прикладі Херсонської державної морської академії (ХДМА).

\section{2. ТЕОРЕТИЧНІ ОСНОВИ ДОСЛІДЖЕННЯ}

У своєму дослідженні ми дотримуємося такого визначення поняття «дистанційне навчання»: це гуманістична особистісно-орієнтована форма навчання, основою якої $є$ цілеспрямоване, мотивоване учіння і спілкування студентів з викладачем та між собою засобами сучасних інформаційних технологій [10, с. 10]. Технології дистанційного навчання розглядаються нами як комплекс освітніх технологій, що включає психологопедагогічні та інформаційно-комунікаційні, що надають можливість реалізувати процес дистанційного навчання у навчальних закладах та наукових установах $[11$, с. 8]. Як поєднання асинхронних Інтернет-технологій навчання та навчання «обличчям до обличчя» (face-to-face) ми розуміємо змішане навчання, що $\epsilon$ ефективною та низькоризиковою стратегією, яка захистить університети від удару технологічних змін, що будуть з'являтися в найближчі кілька років [12, с. 96]. 


\section{3. РЕЗУЛЬТАТИ ДОСЛІДЖЕННЯ}

Використання технологій дистанційного навчання (e-learning, m-learning) не тільки охоплює окремі спеціальності або освітні програми, а є важливим стратегічним інструментом розвитку та позиціонування закладу вищої освіти, сприяє зміцненню інноваційного потенціалу всієї організації, i як наслідок $\epsilon$ підвищенням конкурентоспроможності його випускників. Пануюча сьогодні епоха Web 2.0, епоха інтерактивних Web-peсурсів та спільнот, яка дозволяє користувачу стати активним учасником процесів їх поширення, обговорення та розробки, а також створення індивідуальних навчальних та соціальних просторів, що контролюються навіть 3 мобільного телефону, не може залишати незмінним систему викладання в академії на рівні статичних Web-pecyрсів, що дозволяє тільки читання їх 3 комп’ютера i не дає можливості комунікації або взаємодії. На зміну Web 2.0. приходить Web 3.0 та штучний інтелект, саме тому є необхідність у переосмисленні навчальних концепцій та розробці новітніх освітніх середовищ та стратегій.

На нашу думку, впровадження технологій дистанційного навчання має враховувати індивідуальні когнітивні здібності студентів (персоналізація); включати комунікацію та обмін інформацією на відстані, інтерактивність, мобільність та віртуальну співпрацю. Все це можливо реалізувати в процесі професійної підготовки курсантів морської академії через використання електронного та мобільного навчання, технологій віртуальної та доповненої реальності на тренажерах. I тому сьогодні користується запитом напрям розвитку дистанційної (електронної) освіти.

Розвиток комп'ютерних мережевих технологій стає однією з основ для розвитку дистанційного навчання, електронного та мобільного навчання, які ефективно використовуються для різноманітних форм навчання в ХДМА, зокрема в змішаному навчанні. Відповідно до сучасного рівня розвитку технологій дистанційного навчання в ХДМА створюються та використовуються програмні комплекси та засоби електронного навчання різної спрямованості, у тому числі систем керування навчанням, LMS (Learning Management Systems), що інтегрують у собі засоби для адміністрування, комунікації, оцінювання знань, розробки та супроводу навчальних дистанційних курсів. Так, у 2017 році практично всі предмети у ХДМА мали створені електронні дистанційні курси.

Основною діяльністю у дистанційному навчанні $\epsilon$ самостійна навчальна діяльність студента, тому вкрай необхідним стає гнучка система освіти, що дозволяє набувати знання там і тоді, коли це зручно студенту; а також необхідно, щоб студент навчився самостійно здобувати знання, працювати з інформацією та набув навчальної, а згодом i фахової компетентності. Нині компетентнісний підхід $є$ методичною основою дистанційного навчання. Він дозволяє кожному студенту: активно залучатися у процес засвоєння нового предметного змісту; засвоювати операційно-технічні засоби виконання діяльності; створювати власні освітні траєкторії навчання; самостійно планувати та контролювати ритм та такт підготовки; самостійно планувати та контролювати рівень формування компетентностей.

Кінцевою метою цілепокладання в процесі професійної підготовки курсантів морської академії стають не набуття знань, умінь та навичок, а рівні досягнень їх компетентностей, тобто можливість використання своїх знань, умінь та навичок у конкретній ситуації, а в морській освіті ще й в екстремальних ситуаціях. Державні освітні стандарти спеціальності 271 «Річковий та морський транспорт», за якими має здійснюватися підготовка морських фахівців торгівельного транспорту, нині в стані розробки, тому в процесі професійної підготовки майбутніх морських фахівців навчальні заклади орієнтуються на міжнародні стандарти, що наведені в Міжнародній 
конвенції про підготовку і дипломування моряків та несення вахти 1978 року [13], за якими декларуються обов'язкові мінімальні вимоги до дипломування капітанів i старших помічників капітана, вахтових помічників капітана, старших i других механіків суден, вахтового механіка суден та інших морських фахівців, електромеханіків тощо. Досягти такого рівня в сучасних умовах інтенсифікації підготовки морських фахівців можна завдяки вдосконаленню дистанційного навчання та запровадженню ефективних технологій змішаного навчання. Дистанційне навчання 3 використанням змішаних технологій має бути:

1) менш орієнтованим на курс лекцій та одержання конкретних знань і більш орієнтованим на розвиток певних (загальних і фахових) професійних компетентностей;

2) адаптованим до різних рівнів навчання студентів (низький, середній, високий);

3) максимально наближеним до індивідуальних потреб студентів;

4) дистанційні матеріали мають бути доступні не лише 24/7, а й з будь-яких пристроїв (персональний комп'ютер, планшетний комп'ютер, мобільний телефон) та 3 будь-яких мереж (локальна, глобальна, зокрема супутникова в умовах плавання в морі).

Для реалізації цих напрямів у ХДМА було розроблено структурно-функціональну модель змішаної технології дистанційного навчання (Рис. 1) та створено сайт електронного навчання (https://mdl.ksma.ks.ua).

У ХДМА та Морському коледжі ХДМА (МК ХДМА) для забезпечення дистанційного навчання всі структурні підрозділи виконують відповідні функції, які згруповані у навчальні, методичні та ресурсні. Навчальні та методичні функції виконують деканати, кафедри, відділи та циклові комісії ХДМА та МК ХДМА. Ресурсну функцію виконує Лабораторія інноваційних технологій (ЛІТ), у структурі якої $\epsilon$ Центр оцінювання навчальних досягнень курсантів. У ХДМА та МК ХДМА в процесі підготовки морських фахівців (студентів та курсантів) використовуються:

1) традиційна навчальна діяльність в аудиторії під керівництвом досвідченого викладача;

2) різні шляхи й механізми доставки навчальних матеріалів (друковані матеріали, Інтернет, мобільні мережі) та робота 3 ними (вікі-статті, робота 3 глосарієм, відео завдання, адаптивне тестування тощо);

3) структуроване самостійне навчання, що використовує досвід безпосереднього спілкування курсанта з викладачем та використання навчальних матеріалів онлайн.

Досвід ХДМА та МК ХДМА свідчить, що поєднання традиційної системи освіти 3 дистанційним навчанням, тобто реалізація змішаного навчання (blended learning), $\epsilon$ найбільш ефективним для навчального процесу, особливо в частині спілкування студентів 3 викладачем та між собою. Особливо важливим це виявляється під час дуального навчання курсантів, коли вони в процесі практичної підготовки на судні не відриваються від навчального процесу і продовжують навчання 3 використанням технологій дистанційного навчання.

У процесі змішаного навчання в ХДМА використовується середовище електронного навчання - навчальна платформа Moodle (3.3). Постійне оновлення версій платформи сприяє поліпшенню якості роботи на сайті, удосконаленню тестових завдань та інтерактивних вправ. У березні 2016 академія почала використовувати Moodle 2.9. 


\begin{tabular}{|c|c|c|c|c|}
\hline \multicolumn{2}{|c|}{ ХДМА } & Функції: & \multicolumn{2}{|c|}{ МК ХДМА } \\
\hline Навчальна & Методична & Ресурсна & Навчальна & Методична \\
\hline \multicolumn{2}{|c|}{ Деканати } & ЛIT & \multicolumn{2}{|c|}{ Відділення } \\
\hline \multicolumn{2}{|c|}{ Кафедри } & \multirow[b]{2}{*}{$\begin{array}{l}\text { Забезпечення } \\
\text { комп’ютерною } \\
\text { технікою, } \\
\text { роботи сайту } \\
\text { електронного } \\
\text { навчання } \\
\text { Налагодження } \\
\text { Інтернет-зв’язку. } \\
\text { Забезпечення } \\
\text { бездротовим } \\
\text { доступом до } \\
\text { Інтернет (Wi-Fi). } \\
\text { Налаштування } \\
\text { системи відео } \\
\text { фіксації } \\
\text { тестування. }\end{array}$} & \multicolumn{2}{|c|}{ Циклові комісії } \\
\hline $\begin{array}{l}\text { Визначення } \\
\text { фахових } \\
\text { компетентнос } \\
\text {-тей і } \\
\text { результатів } \\
\text { навчання. } \\
\text { Визначення } \\
\text { структури } \\
\text { навчання } \\
\text { Оцінювання } \\
\text { навчальних } \\
\text { досягнень } \\
\text { Порівняння } \\
\text { отриманих } \\
\text { результатів } \\
\text { навчання із } \\
\text { заплановани } \\
\text { ми, } \\
\text { визначення } \\
\text { рівня } \\
\text { компетентнос }\end{array}$ & $\begin{array}{l}\text { Визначення } \\
\text { структури } \\
\text { навчання. } \\
\text { Визначення } \\
\text { викладачами } \\
\text { структури } \\
\text { навчальної } \\
\text { програми. } \\
\text { Викладацька } \\
\text { діяльність } \\
\text { професорськ } \\
\text { о- } \\
\text { викладацьког } \\
\text { о складу. } \\
\text { Заходи із } \\
\text { забезпечення } \\
\text { якості } \\
\text { навчальних } \\
\text { програм для } \\
\text { отримання } \\
\text { ступеню }\end{array}$ & & $\begin{array}{l}\text { Визначення } \\
\text { фахових } \\
\text { компетентносте } \\
\text { й та результатів } \\
\text { навчання. } \\
\text { Визначення } \\
\text { результатів } \\
\text { навчання (ІМО } \\
\text { модельні курси). } \\
\text { Визначення } \\
\text { структури } \\
\text { навчання. } \\
\text { Оцінювання } \\
\text { навчальних } \\
\text { досягнень. } \\
\text { Порівняння } \\
\text { отриманих } \\
\text { результатів } \\
\text { навчання із } \\
\text { запланованими, } \\
\text { визначення } \\
\text { рівня }\end{array}$ & $\begin{array}{l}\text { Визначення } \\
\text { структури } \\
\text { навчання. } \\
\text { Визначення } \\
\text { викладачами } \\
\text { структури } \\
\text { навчальної } \\
\text { програми. } \\
\text { Викладацька } \\
\text { діяльність } \\
\text { професорськ } \\
\text { о- } \\
\text { викладацьког } \\
\text { о складу. } \\
\text { Заходи із } \\
\text { забезпечення } \\
\text { якості } \\
\text { навчальних } \\
\text { програм для } \\
\text { отримання } \\
\text { ступеню } \\
\text { вишої освіти. }\end{array}$ \\
\hline
\end{tabular}

\begin{tabular}{|c|c|c|c|c|c|}
\hline \multicolumn{6}{|c|}{ Технологї: } \\
\hline \multirow{2}{*}{$\begin{array}{l}\text { Змішане } \\
\text { навчання }\end{array}$} & Дистанг & навчання & \multicolumn{3}{|c|}{ Мобільне навчання } \\
\hline & \multicolumn{2}{|c|}{ Навчання face-to-face } & \multicolumn{3}{|c|}{ Віртуальна і доповнена реальність } \\
\hline \multicolumn{6}{|c|}{ Структура електронного курсу: } \\
\hline Анотація & Сіллабус & \multicolumn{2}{|c|}{ Інтерактивні елементи } & Тест & Опитування \\
\hline \multicolumn{6}{|c|}{ Функції викладачів: } \\
\hline \multicolumn{2}{|c|}{ Інформативна } & альна & \multicolumn{2}{|c|}{ Тренувальна } & Контролююча \\
\hline
\end{tabular}

Мета: удосконалення професійної підготовки майбутніх фахівців морської галузі

Рис. 1. Структурно-функиіональна модель зміманої технологї̈ дистаниійного навчання ХДМА 
У вересні 2017 року був здійснений перехід на LMS Moodle 3.3. (Рис. 2), яка містить нові можливості у набутті та використанні компетентностей [14], покращений зворотній зв'язок між викладачем та студентом, а також має можливість інтерактивних звітів, удосконалену медіа підтримку та суттєво змінений інтерфейс.

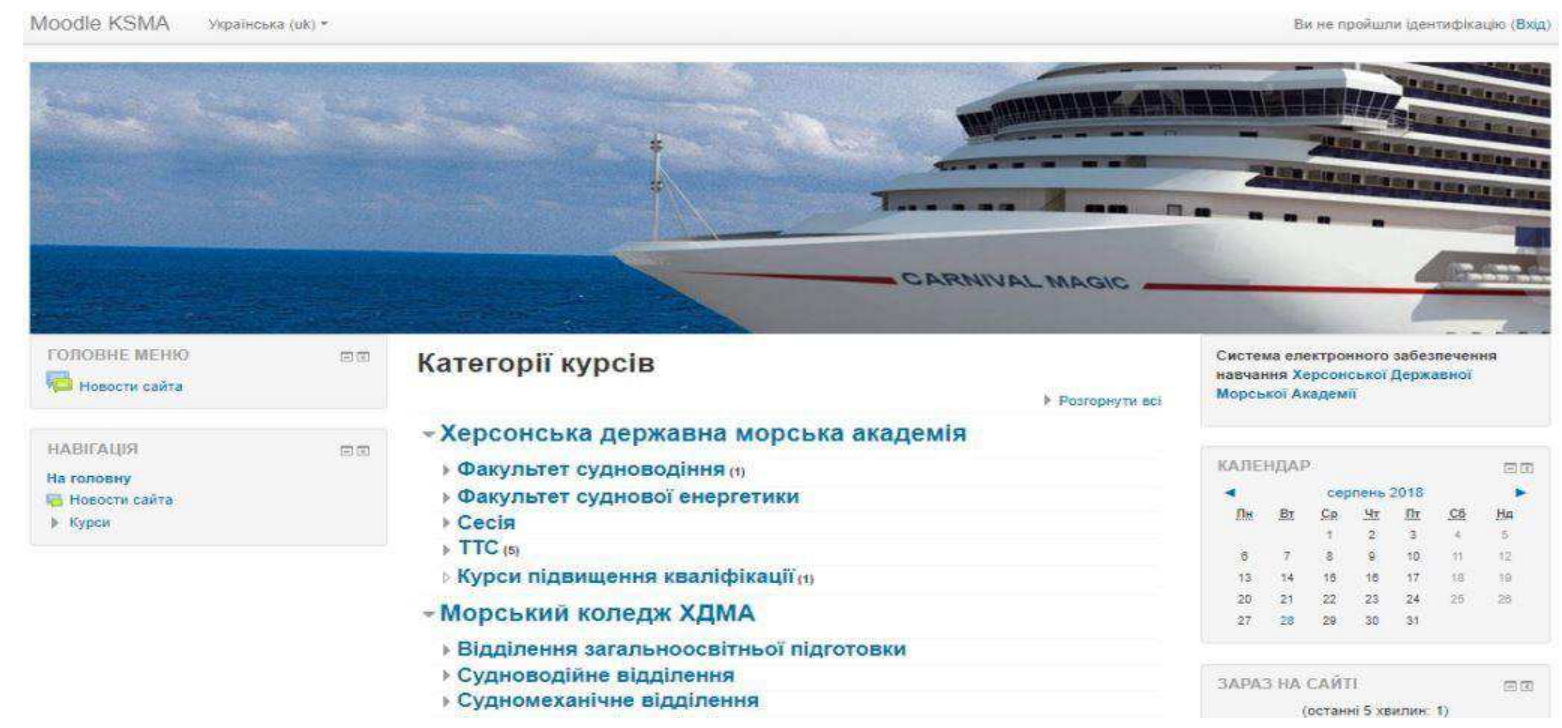

Рис. 2. Головна сторінка сайту електронного навчання ХДМА

У процесі використання навчальної платформи LMS Moodle курсанти академії отримують доступ до відеолекцій, завдань для самостійного опрацювання та тестових матеріалів, спілкуються з викладачами та іншими студентами, мають змогу опрацювати додатковий матеріал з певної тематики. Однією з переваг впровадження дистанційного навчання у ХДМА $є$ можливість використовувати його для організації самостійної роботи курсантів. Система забезпечує як викладачам, так і курсантам необмежений доступ до освітніх ресурсів. Так у курсах викладені довідкові, методичні матеріали, рекомендації щодо виконання практичних та лабораторних занять, тестові завдання 3 автоматичною перевіркою. Крім того, електронні курси Moodle містять такі форми робіт, які недоступні на звичайних заняттях, але зручні та ефективні для занять вдома, такі, як форуми, чати, пошта, презентації, відеоконференції, опитування, Вікі тощо. Структура дистанційного курсу у ХДМА має такі елементи: інтерактивні елементи (форум, чат, опитування), елементи для діагностики навчальних досягнень студентів (тренувальні тести, анкети, Scorm-пакети, сервіси Web 2.0 , завдання, тести, есе, робочі зошити); елементи представлення навчального матеріалу (посилання на Інтернетресурси, You Tube, файли, глосарій, текстові матеріали (Рис. 3).

Новим у системі дистанційного навчання ХДМА стало додавання до кожної навчальної діяльності компетентності з переліку компетентностей, що запропоновані в міжнародних стандартах, і автоматичне відслідковування їх набуття студентами, що реалізовано в новій версії в Moodle. Завдяки застосуванню такої технології викладач бачить протягом курсу, які компетентності вже набуті студентами, а які вимагають додаткової уваги. Перебіг набуття студентом компетентностей відображається візуально у блоці «Learning plans» на сторінці курсу. Викладач може додати цей блок на свою сторінку інформаційної панелі, і будь-які компетентності, надіслані для перегляду їх студентами, будуть видимі в цьому блоці. 


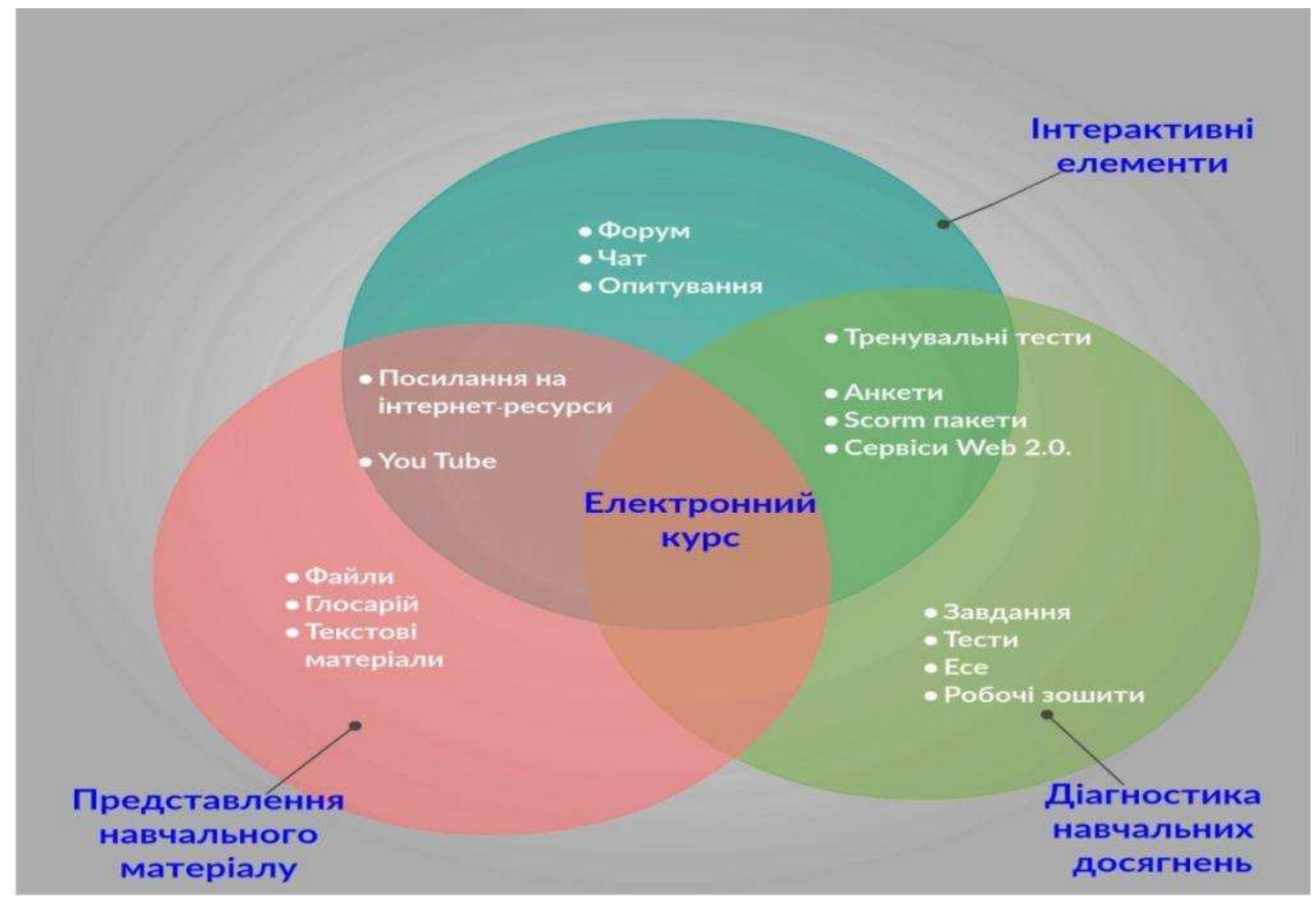

Рис. 3. Структура електронного курсу у моделі ХДМА

Електронний формат навчального курсу надає можливість курсантам навчатися за індивідуальним освітнім маршрутом. Матеріали та завдання, які використовуються під час проходження курсу, мають велику ступінь варіативності, побудовані з урахуванням таксономії Блума. Викладачі дозволяють курсантам обрати, у якому темпі і в якій послідовності освоювати обов'язкові матеріали курсу та в який спосіб вивчати додаткові або дотичні до нього матеріали.

Кожному викладачу обов'язково потрібно визначити, які компетентності та результати навчання потрібно набути та продемонструвати курсантам після проходження курсу, і розробити загальну структуру курсу. Для цього у версії 3.3. додано функціонал по роботі з компетентностями [14]: якщо компетентності дозволені в системі адміністратором сайту, викладач може перелічити ті 3 них, які будуть формуватися при вивченні курсу, а студент може бачити (але не змінювати) компетентності, пов'язані з курсом.

Система Moodle дозволяє не тільки надавати різноманітні навчальні матеріали 3 дисципліни (модулю), але й містить технологічні інструменти для виконання різноманітних завдань та оцінювання освітнього процесу, включаючи самостійну роботу студентів. Увесь технологічний інструментарій Moodle можна виокремити в статичну (ресурси курсу) й інтерактивну (елементи курсу) групи.

Основні структурні елементи електронного навчального курсу у моделі ХДМА:

- анотація - визначає особливості змісту курсу, мету та очікувані результати навчання;

- сіллабус - система оцінювання курсу з визначенням балів;

- ресурси - представлення навчального матеріалу у вигляді текстових файлів i/чи Web-сторінок, посилань на Інтернет-ресурси, відео та аудіо-матеріали;

- інтерактивні елементи: інтерактивна лекція, що містить теоретичний матеріал завершується питаннями, залежно від відповіді на які студент спрямовується 
по індивідуальному маршруту; інтерактивне завдання (наприклад, у LearningApps); віртуальні тренажери;

- тест - засіб контролю знань;

- опитування - засіб анкетування або голосування курсантів для отримання зворотного зв' язку.

Серед основних форм, які використовуються для оцінки компетентностей, використовуються: тестування, захист проектних завдань та портфоліо, аналіз презентацій та текстів, рішень кейс-завдань.

Працюючи в системі LMS Moodle, викладачі академії у своїй роботі використовують такі функції:

1. Інформативна: курсант має доступ до необхідної інформації чи ресурсу 24 години на добу; курсант та його батьки поінформовані про результати роботи протягом семестру; інформація для курсантів та студентів щодо умов домашнього завдання та вивченого матеріалу 3 метою надання допомоги курсантам, які мають пропуски навчальних занять.

2. Навчальна: для курсантів створюються навчальні та тренувальні вправи. Система LMS Moodle має широкі можливості для створення інтерактивних та візуальних вправ (вбудовані тренувальні презентації, відео, анімовані вправи, форуми, прослуховування діалогів, Інтернет-ресурси тощо).

3. Тренувальна: використання елементів гейміфікації як одного із засобів запам'ятовування інформації. Такі вправи є дуже цікавими та інтерактивними, курсанти виконують їх із задоволенням.

4. Контролююча: проведення поточного електронного тестування, яке може бути формативним, сумативним або підсумковим. Електронний курс зазвичай складається із кількох тематичних модулів, кожний 3 яких завершується електронним тестуванням. Викладачі формують банк завдань, 3 якого обирається певна кількість питань для кожного курсанта.

Прикладом використання змішаних технологій дистанційного навчання 3 дисциплін циклу професійної підготовки можна навести вивчення дисципліни «Деталі машин», у якій використовується можливість проводити деталіровку частин машин та будувати епюри 3 напружено-деформованого стану деталей. Маючи шкалу напруженого стану можна з'ясовувати найбільш вразливі місця та проводити заходи із забезпечення роботоспроможності.
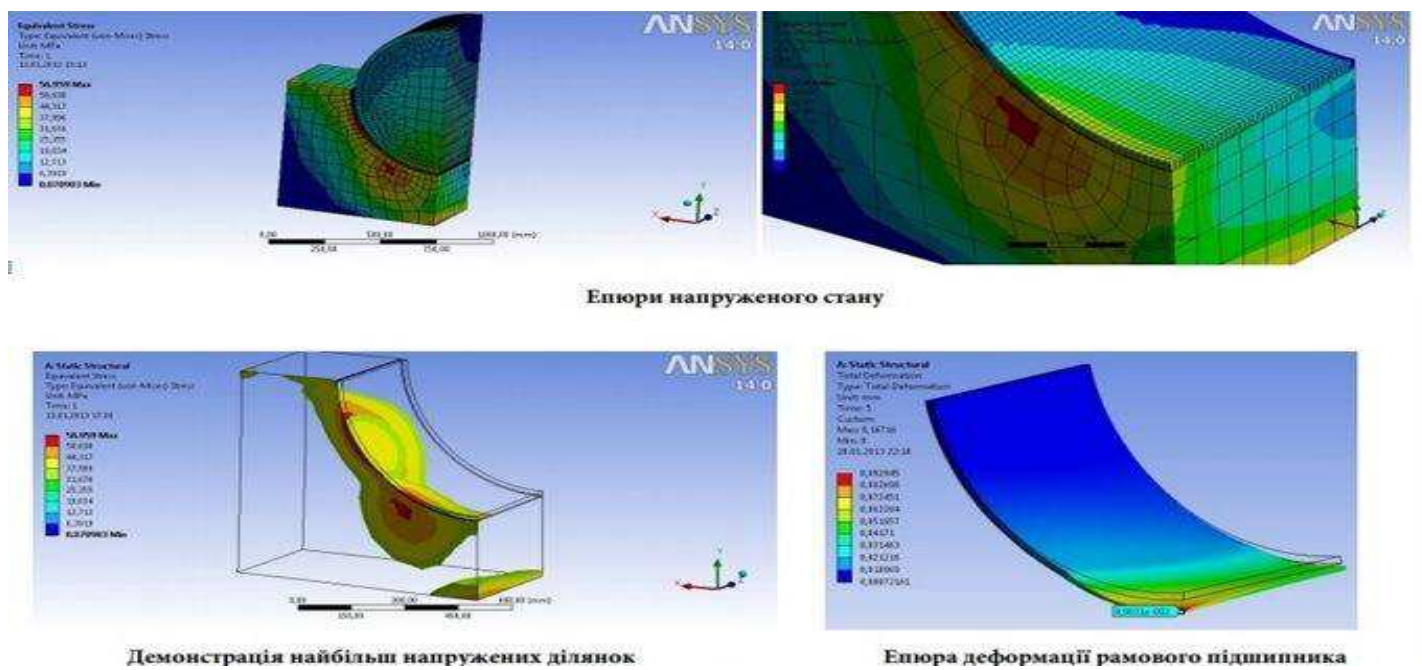

Рис. 4. Результати напружено-деформованого стану рамового підиипника мало обертового дизеля 
Також під час проведення дипломного проектування можна вирішувати обернену задачу: проектування за визначеними вимогами деталей машин та механізмів. Моделюючи роботу деталей у режимі реального часу, враховуючи дію сил, які впливають на роботу машини, можна спроектувати деталі.
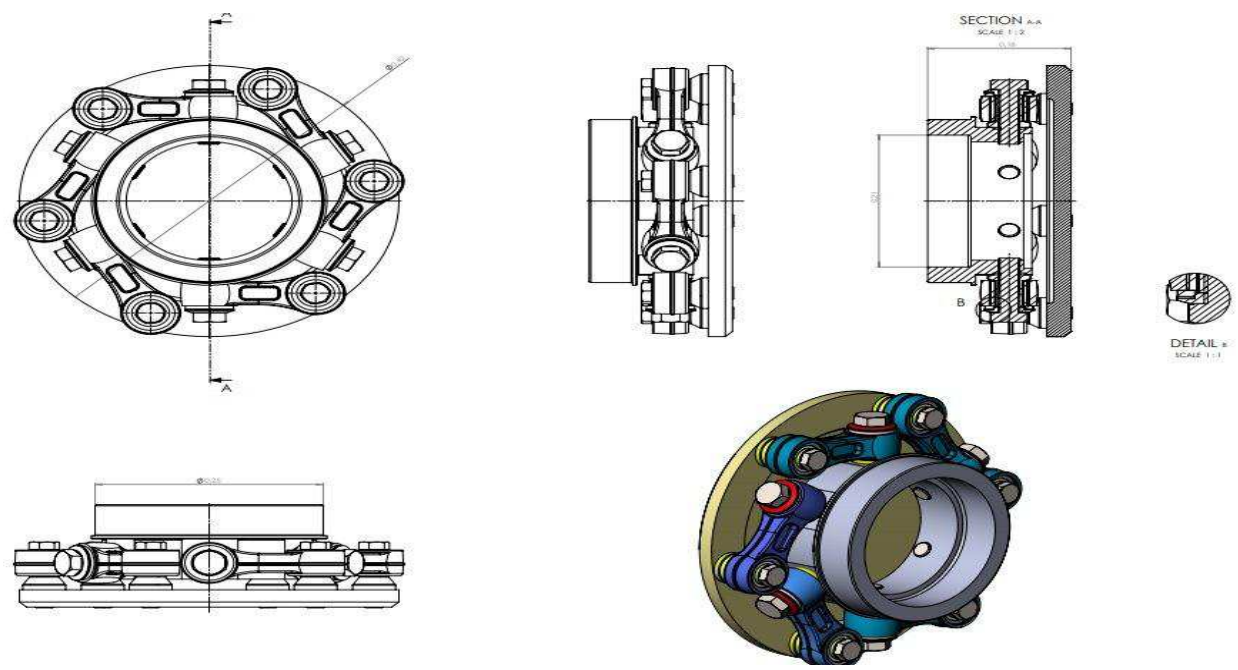

Рис. 5. 3D модель та ескіз креслення з'єднувальної муфти передачі обертального моменту у валопроводі.

Під час вивчення дисципліни «Експлуатація суднового двигуна» $є$ необхідність вивчення конструкції поршнів та визначення місць максимальної загрузки, яка може призвести до аварії. То ж студентам створюється модель максимально наближена до реальної, робиться розріз, а потім проводиться аналіз із визначення розподілу напружень та будується епюра розподілу переміщень.
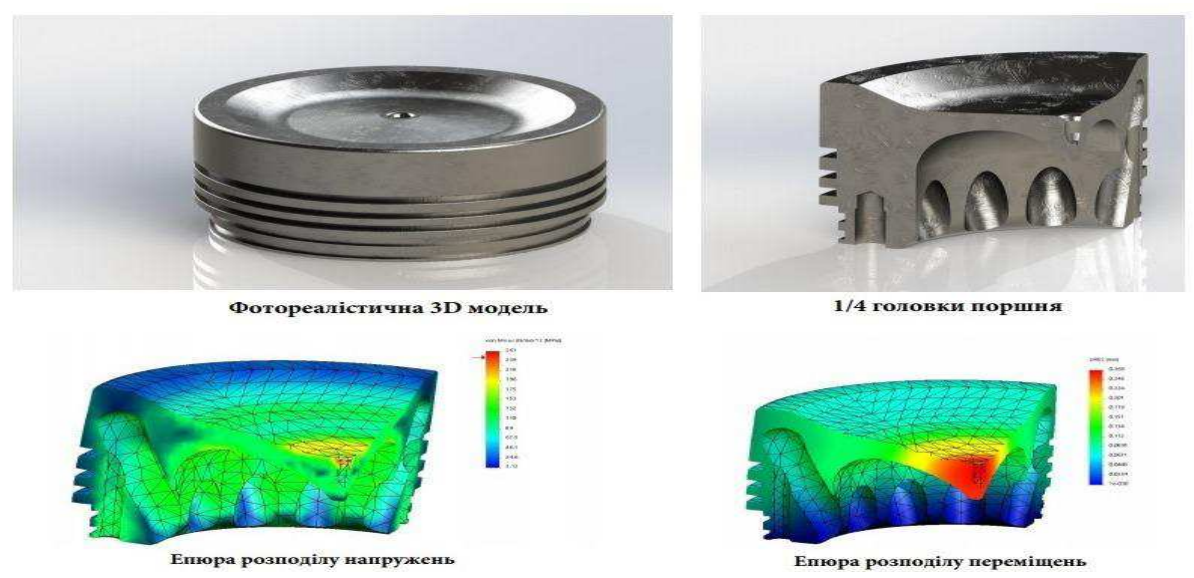

Рис. 6. Дослідження напружено-деформованого стану головки поршня дизельного двигуна.

Окрім цього у ХДМА особлива увага звертається на удосконалення навчання англійській мові, що пов'язано із специфікою майбутньої професійної діяльності курсантів. Особлива увага в процесі навчання англійській мові засобами технологій дистанційного навчання 3 усіх перелічених функцій приділяється тренувальній. За допомогою додаткового сервісу LearningApps викладачами розробляються тренувальні вправи для вивчення англійської мови. 
Онлайновий сервіс LearningApps (https://learningapps.org) дозволяє створювати інтерактивні вправи. За допомогою завдань, створених у цьому додатку, курсанти можуть перевірити й закріпити свої знання в ігровій формі, що сприяє формуванню їх пізнавального інтересу. Сервіс LearningApps надає можливість отримання коду для того, щоб інтерактивні завдання було розміщено на сторінці навчальної платформи Moodle.

Наприклад, засобами цього сервісу можна розробити різні інтерактивні вправи, які мають ігровий аспект і можуть бути застосовані не лише для вивчення англійської мови, а й для викладання різних дисциплін у професійній підготовці майбутніх фахівців морської галузі. Це зокрема: «Знайти пару», «Класифікація», «Числова пряма», «Просте упорядкування», «Вільна текстова відповідь», «Фрагменти зображення», «Вікторина», «Заповнити пропуски», «Перший мільйон», «Пазл», «Кросворд», «Знайти на карті», «Знайти слова», «Де це?», «Вгадай слово», «Скачки», «Парочки», «Порахувати», «Інструменти», «Голосування» та ін..

Наприклад, ігрове завдання «Вгадай слово» (Рис. 7) за допомогою дефініції дозволяє сформувати навички правильного написання англійських слів та розуміння їх семантики. У вправі потрібно вгадати слово за підказкою, клацаючи на букви, що знаходяться внизу вправи. Ця вправа подібна до гри «Поле чудес», проте, на відміну від неї, у вправі обмежена кількість спроб вгадування літер.

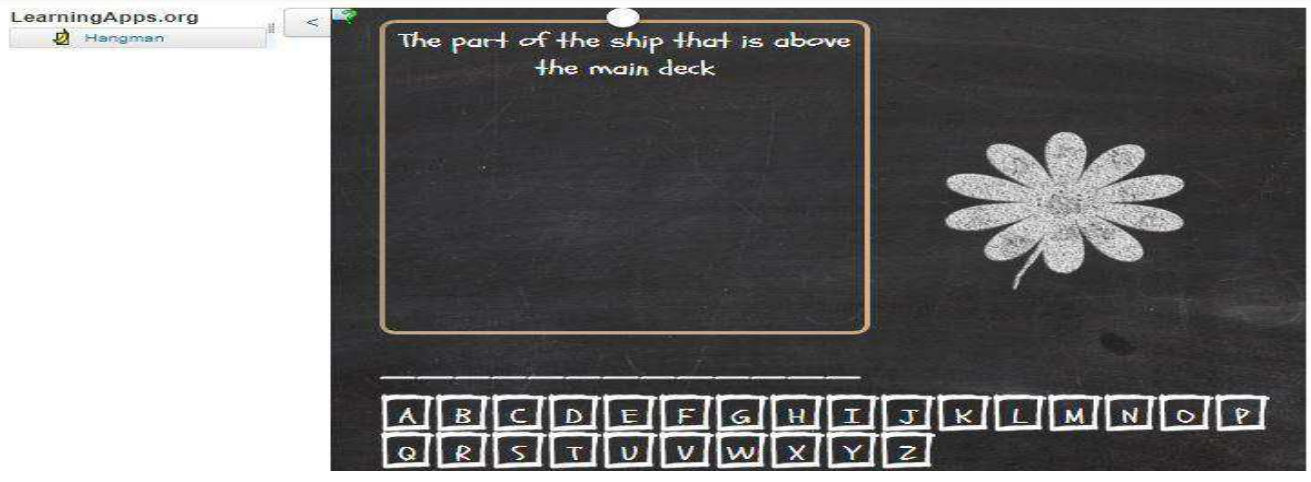

Рис. 7. Ігрове завдання «Вгадай слово»

Мета ігрового завдання «Заповнити пропуски» (Рис. 8) - вибрати зі списку потрібне пропущене слово та заповнити ним пропуски.

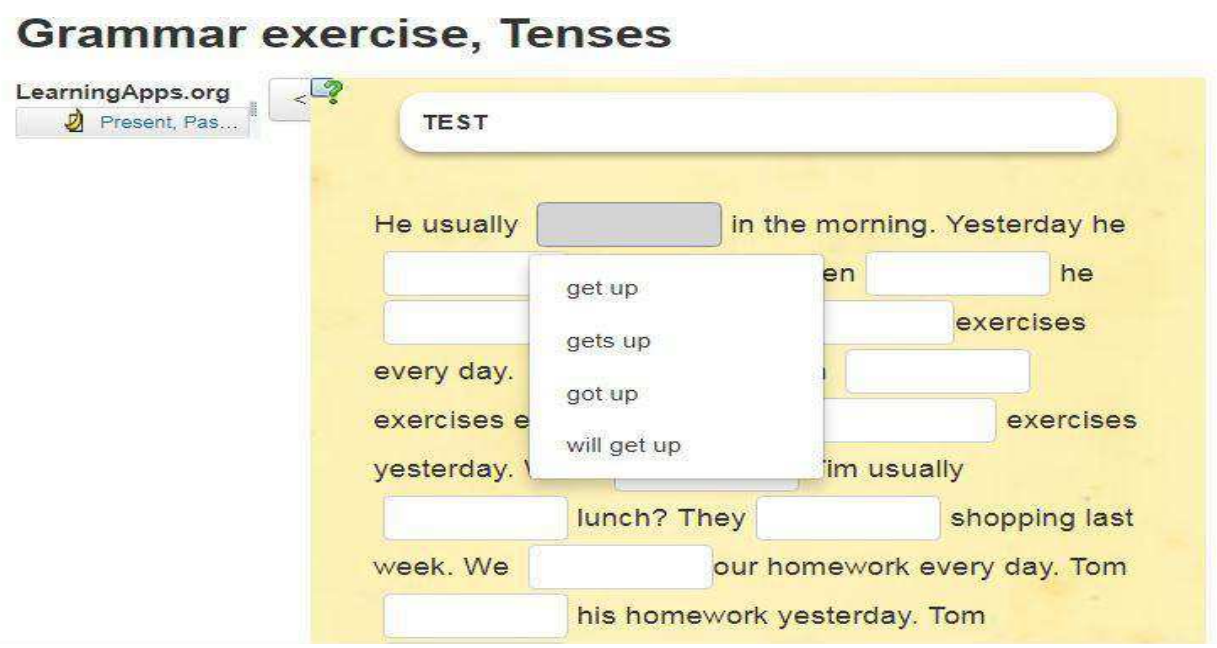

Рис. 8. Ігрове завдання «Заповнити пропуски» 
Використовуючи тип вправи «Кросворд» (Рис. 9) можна вивчати лексику i граматику англійської мови та назви частин судна.
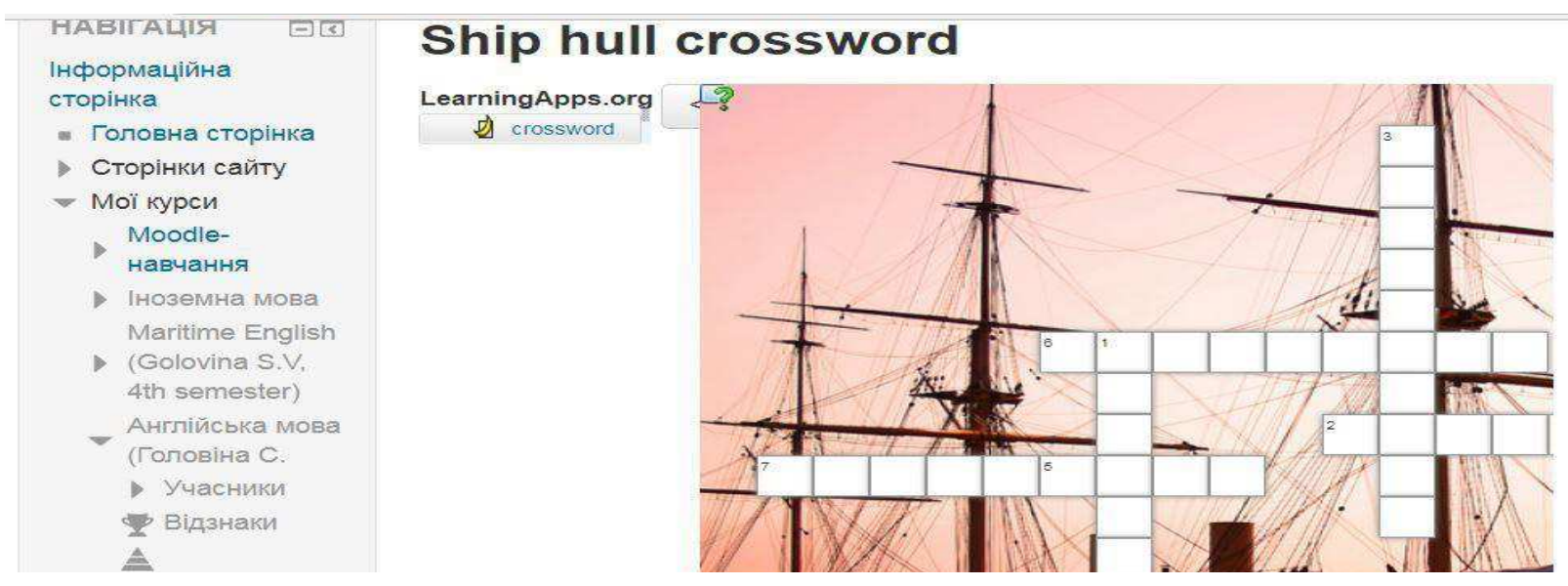

Рис. 9. Ігрове завдання «Кросворд»

Ігрове завдання «Перегони» (Рис. 10) є цікавою інтерактивною грою, у якій може брати участь декілька курсантів одночасно. Її мета - дійти до фінішу, виконуючи запропоновані у грі завдання, які публікуються у верхній частині екрану. У нижній частині додаються варіанти відповіді. Курсанти по черзі дають відповіді на питання. У результаті, той, хто зробив менше помилок, стає переможцем. Такий змагальний момент також підвищує пізнавальну активність курсантів.

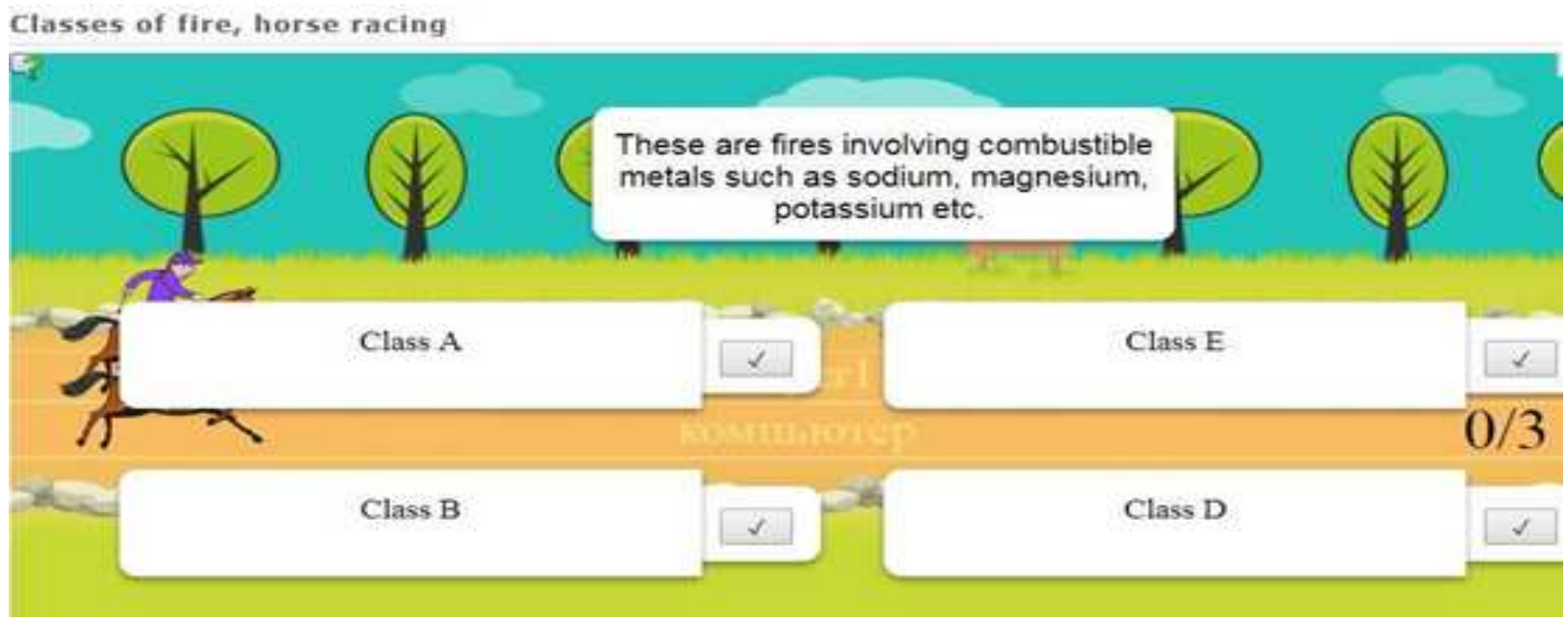

Рис. 10. Ігрове завдання «Перегони»

За допомогою ігрового завдання «Класифікація» можна за різними ознаками розподіляти слова, малюнки, аудіо, відео на групи (Рис. 11). У цій грі відпрацьовуються не лише знання з англійської мови, а й знання з питань ліквідації пожеж на судні, адже в наведеному на рис. 11 завданні студентам потрібно розподілити типи загоряння за класами пожеж. 


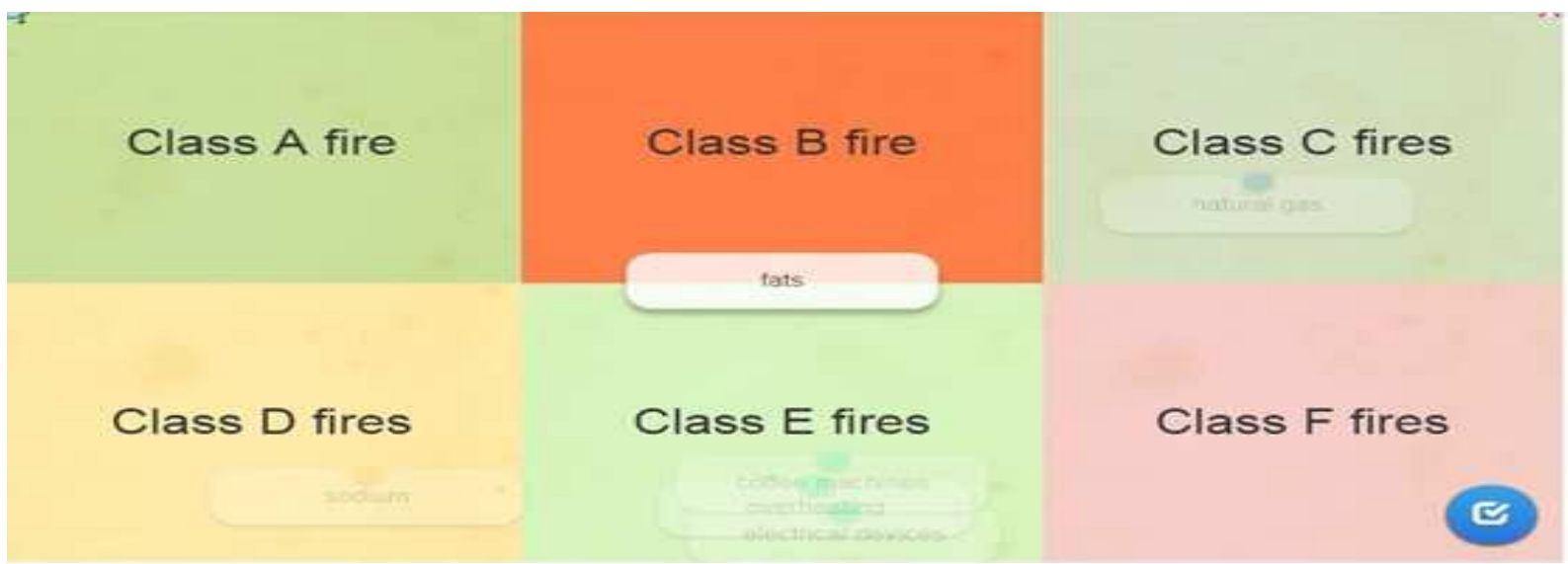

Рис. 11. Ігрове завдання «Класифікація»

За допомогою ігрового завдання «Знайди пару» (Рис. 12) можна підібрати пари (слова та малюнки, відео, аудіо тощо). У цьому завданні, крім тренування англійської лексики, студенти вчать назви міжнародних знаків, які їм знадобляться в майбутній професійній діяльності.

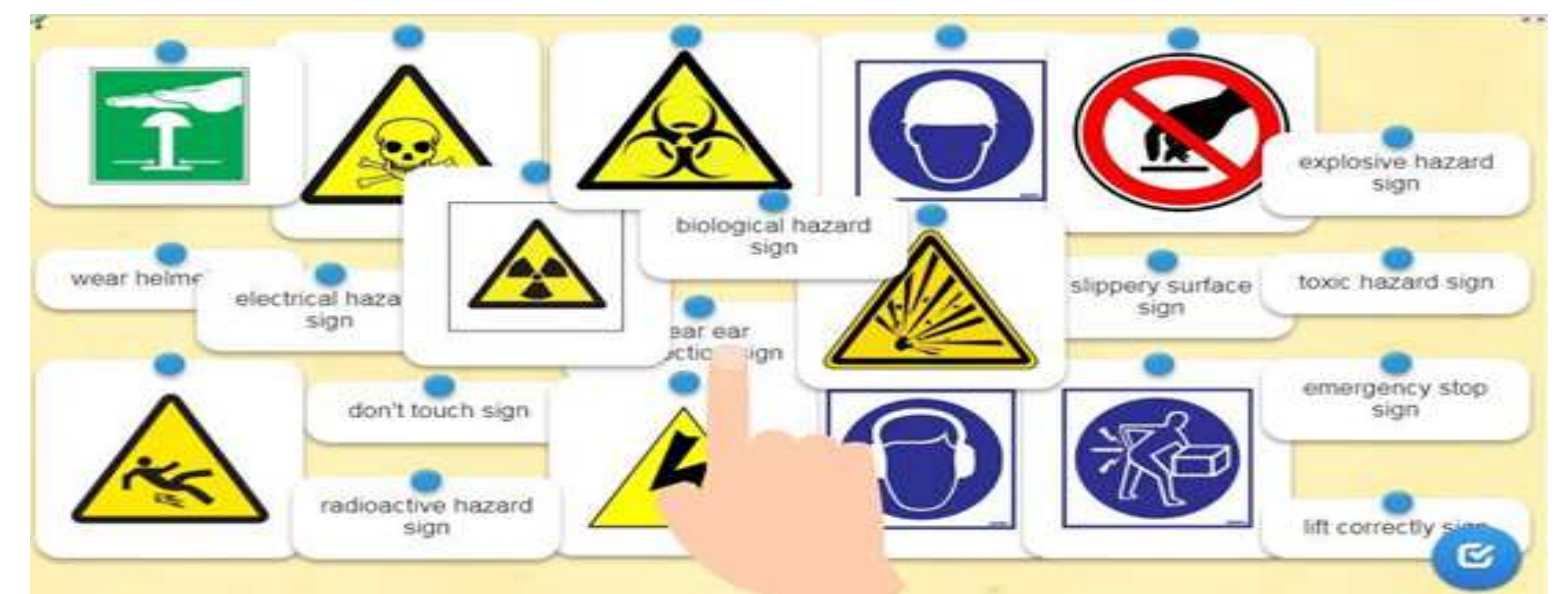

Рис. 12. Ігрове завдання «Знайди пару»

В ігровому завданні «Просте упорядкування» (Рис. 13) курсантам потрібно розташувати слова в правильній послідовності, щоб отримати речення.

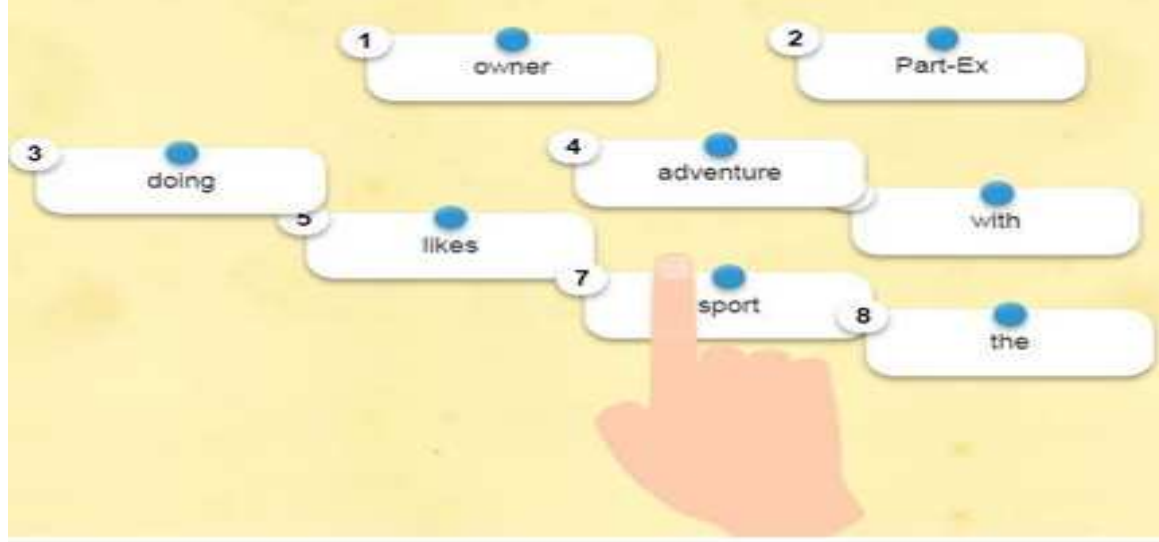

Рис. 13. Ігрове завдання «Просте упорядкування» 
Оскільки однією з вимог Міністерства освіти і науки України для впровадження дистанційного навчання $є$ відповідна підготовка науково-педагогічних працівників щодо організації та володіння технологіями дистанційного навчання, у ХДМА для навчання викладацького складу в системі Moodle розроблені навчальні електронні курси. Зокрема було розроблено шеститижневий курс «Компетентнісний підхід в електронному навчанні». Він спрямований на розвиток науково-методичної компетентності викладача; розвиток здатності керувати професійними інноваціями; удосконалення готовності до реалізації компетентнісного підходу при викладанні предмету та здатності до науково-методичного супроводу компетентнісного підходу; формування вміння здійснювати викладання з використанням дистанційних технологій. Курс складається 3 теоретичного матеріалу, практичних завдань та тестів у кінці вивчення кожної теми.

Важливим у впровадженні змішаних технологій дистанційного навчання $є$ те, що система дистанційного навчання не є статичною, а постійно розвивається. До цього процесу залучені всі учасники навчального процесу (викладачі, студенти, адміністратори системи електронного навчання), які постійно розробляють та вдосконалюють електронні курси. Постійний моніторинг у ХДМА інформації щодо досягнень сучасних інформаційних та педагогічних технологій спонукає до вдосконалення вже напрацьованих технологій та постійного підвищення професійної кваліфікації викладачів академії, що, у свою чергу, сприяє підвищенню ефективності професійної підготовки майбутніх морських фахівців.

\section{4. ВИСНОВКИ ТА ПЕРСПЕКТИВИ ПОДАЛЬШИХ ДОСЛІДЖЕНЬ}

Отже, протягом запровадження змішаного навчання в професійній підготовці курсантів Херсонської державної морської академії виявлено трансформаційний потенціал освітнього закладу, що дозволить удосконалити професійну підготовку майбутніх фахівців морської галузі з урахуванням тенденцій сучасного розвитку цифрових технологій та цифрового суспільства. 3'ясовано, що інтерактивні інформаційні та комунікаційні засоби Інтернету забезпечують гнучкість у використанні часу й місця навчання курсантів та реальність необмеженого освітнього дискурсу. На практиці ХДМА доведено, що найкраще використовувати поєднання синхронного («обличчям до обличчя») та асинхронного (Інтернет) навчання для цілей оптимізації професійної підготовки майбутніх фахівців морської галузі. Мету подальших наукових розвідок вбачаємо в проведенні експериментальних досліджень результатів запровадження змішаного навчання в плані впливу на ефективність професійної підготовки морських фахівців.

\section{СПИСОК ВИКОРИСТАНИХ ДЖЕРЕЛ}

[1] Постанова "Про затвердження Морської доктрини України на період до 2035 року" від 7 жовтня 2009 p. №1307. [Електронний ресурс]. Доступно: http://zakon3.rada.gov.ua/laws/show/1307-2009\%D0\%BF. Дата звертання: серпень 23, 2018.

[2]Paris Communiqué Paris, 25th May, 2018. [Електронний ресурс]. Доступно: http://erasmusplus.org.ua/images/phocadownload/HERE_doc/PARIS\%20COMMUNIQU_En_UA_2018. docx. Дата звертання: серпень 26, 2018.

[3] B.Wang, and H. Xing, "The application of cloud computing in education informatization", in International Conference Computer Science and Service System (CSSS), 27-29 June 2011, pp. 2673-2676.

[4] В.Ю. Биков, "Сучасні завдання інформатизації освіти", Інформаційні технологіі $і$ засоби навчання, № 12010 (15), [Електронний ресурс]. Доступно: https://journal.iitta.gov.ua/index.php/itlt/article/view/25/13. Дата звертання: серпень 27, 2018. 
[5] А.Ю. Пилипчук, "Реформування освіти та інформатизація: основні проблеми і підходи до їх рішення", Інформаційні технологї $i$ засоби навчання, № 1 (5), 2008. [Електронний ресурс]. Доступно: https://journal.iitta.gov.ua/index.php/itlt/article/view/155/141. Дата звертання: серпень 27, 2018.

[6] В.В.Осадчий, та К.П. Осадча, "Сучасні реалії і тенденції розвитку інформаційно-комунікаційних технологій в освіті", Інформаційні технології $і$ засоби навчання, т. 48, № 4, с. 47-57, 2015.

[7] Т.І. Коваль, "Особливості впровадження дистанційних технологій навчання у вищій школі в умовах соціоекономічних трансформацій" на Всеукраїнська науково-практична конференція «Освітологія - науковий напрям інтегрованого пізнавання освіти», 2010, с. 54-58.

[8] В.В. Олійник, Відкрита післядипломна педагогічна освіта $і$ дистанційне навчання в запитаннях $i$ відповідях. Київ, Україна: "А.С.К", 2013.

[9] К.Л. Бугайчук, "Змішане навчання: теоретичний аналіз та стратегія впровадження в освітній процес вищих навчальних закладів", Інформащчійні технології $i$ засоби навчання, 2016, № 4 (54). [Електронний ресурс]. Доступно: http://journal.iitta.gov.ua/index.php/itlt/article/view/1434. Дата звертання: жовтень 05, 2018.

[10] О.В. Кареліна, "Формування умінь з інформаційних технологій у процесі дистанційного навчання студентів вищих економічних навчальних закладів", автореф. дис. канд. пед. наук. Тернопільський національному педагогічний університет імені Володимира Гнатюка, Тернопіль, 2005.

[11] К.П. Осадча, та В.В. Осадчий, Технології дистанційного навчання. Робота 3 Moоdle 2.4, Мелітополь, Україна: Вид-во МДПУ ім.Б.Хмельницького, 2014.

[12] D.R. Garrison, and H. Kanuka, "Blended Learning: Uncovering Its Transformative Potential in Higher Education", Internet and Higher Education, 7 (2), 95-105, 2004.

[13] Міжнародна конвенція про підготовку і дипломування моряків та несення вахти 1978 року. [Електронний ресурс]. Доступно: http://zakon0.rada.gov.ua/laws/show/995_053. Дата звертання: жовтень 05, 2018.

[14] Competencies. [Електронний ресурс]. Доступно: https://docs.moodle.org/33/en/Competencies. Дата звертання: серпень, 26, 2018.

Матеріал надійшов до редакиї 07.09.2018 p.

\title{
ВНЕДРЕНИЕ СМЕШАННОГО ОБУЧЕНИЯ В ПРОФЕССИОНАЛЬНУЮ ПОДГОТОВКУ БУДУЩИХ СПЕЦИАЛИСТОВ МОРСКОЙ ОТРАСЛИ
}

\author{
Волошинов Сергей Анатольевич \\ кандидат педагогических наук, \\ доцент кафедры инновационных технологий и технических средств судовождения \\ Херсонская государственная морская академия, г. Херсон, Украина \\ ORCID ID 0000-0001-9127-9999 \\ s_voloshinov@ukr.net
}

Аннотация. Автор актуализирует проблему внедрения смешанного обучения в профессиональную подготовку будущих специалистов морской отрасли. На основе анализа исследований по применению цифровых технологий в профессиональной подготовке будущих специалистов морской отрасли сделан вывод о том, что применение смешанного обучения в подготовке морских специалистов требуют дальнейшего теоретического осмысления и практической реализации. В статье осуществлено описание практического опыта применения смешанного обучения в образовательном процессе Херсонской государственной морской академии (ХГМА). Отмечается, что компетентностный подход является методической основой смешанного обучения, ведь целью профессиональной подготовки будущих специалистов морской отрасли становятся не приобретение знаний, умений и навыков, а уровни достижений ими компетентностей, то есть их способность использовать свои знания, умения и навыки в конкретной профессиональной ситуации. Автором поданы направления совершенствования применения смешанного обучения в ХГМА. Сосредоточено внимание на использовании LMS Moodle в организации асинхронного обучения будущих специалистов морской отрасли. Предложена структурнофункциональная модель применения смешанного обучения в профессиональной подготовке курсантов ХГМА. В ней акцентировано внимание на функциях структурных подразделений академии в организации смешанного обучения, его реализации, уточнении структуры 
электронного курса, функциях преподавателей и интерактивных средств обучения. Приведен пример применения сервиса LearningApps в обучении английскому языку будущих специалистов морской отрасли, а именно использование игровых заданий «Угадай слово», «Заполнить пробелы», «Кроссворд», «Гонки», «Классификация», «Найди пару», «Простое упорядочение». Отмечено, что важное значение для внедрения смешанного обучения приобретает соответствующая подготовка научно-педагогических работников и владение ими цифровых технологий. Для этого организовано повышение квалификации преподавательского состава в LMS Moodle путем обучения на электронных курсах.

Ключевые слова: смешанное обучение; профессиональная подготовка; морские специалисты; LMS Moodle, LearningApps.

\title{
IMPLEMENTATION OF BLENDED LEARNING IN PROFESSIONAL TRAINING OF FUTURE MARINE SPECIALISTS
}

\author{
Serhii A. Voloshynov \\ $\mathrm{PhD}$ of Pedagogical Sciences, Associate Professor of the Department of Innovative Technologies \\ and Technical Means of Navigation \\ Kherson State Maritime Academy, Kherson, Ukraine \\ ORCID ID 0000-0001-9127-9999 \\ s_voloshinov@ukr.net
}

\begin{abstract}
The author actualizes the problem of introducing blended learning in training process of future mariners. The conclusion that blended learning for marine specialists requires further theoretical reflection and practical implementation is based on the analysis and research of the use of digital technologies in the training of future mariners. The article describes the practical experience of blended learning use in the educational process of the Kherson State Maritime Academy (KSMA). It is noted that the competency approach is the methodological basis of blended learning, since the goal of future specialists training in the maritime industry is not the acquisition of knowledge, skills and abilities, but the level of achievements of their competencies, that is, the ability to use their knowledge, skills, and abilities in a professional situation. There are given the ways of blended learning improvement in the KSMA. The focus is on the use of LMS Moodle in organizing asynchronous training for future marine professionals. The application of blended learning model in the professional training of KSMA is proposed. The focus in the model is on the functions of KSMA structural units in the organization and implementation of blended learning, the e-courses' structure is clarified, the functions of teachers and interactive means of training are also made clear. The example of 3D modelling and LearningApps application resources in the learning of English for future mariners is shown («Guess the Word», «Fill in the Gaps», «Crossword», «Horse race», «Group assignment», «Matching pairs», «Simple order» activities). It is noted that introduction of blended learning in the training of academic staff and their possession of digital competencies is important. To do this, in the proposed model, the advanced training of the teaching staff in LMS Moodle is implemented through training on ecourses.
\end{abstract}

Keywords: blended learning; professional training; marine specialists; LMS Moodle, LearningApps.

\section{REFERENCES (TRANSLATED AND TRANSLITERATED)}

[1] The Resolution "On Approval of the Marine Doctrine of Ukraine for the Period until 2035" of October 7 2009. №1307. [online]. Available: URL: http://zakon3.rada.gov.ua/laws/show/1307-2009-\%D0\%BF. Accessed on: August 23, 2018. (in Ukrainian).

[2]Paris Communiqué Paris, 25th May, 2018. [online]. Available: http://erasmusplus.org.ua/images/phocadownload/HERE_doc/PARIS\%20COMMUNIQU_En_UA_2018. docx. Accessed on: August 26, 2018. (in English).

[3] B.Wang, and H. Xing, The application of cloud computing in education informatization, in Computer Science and Service System (CSSS), International Conference, 27-29 June 2011, pp. 2673-2676. 
[4] V.Y. Bykov, "Modern tasks of informatization of education", Information Technologies and Learning Tools, № 1 (15), 2010. [online]. Available: https://journal.iitta.gov.ua/index.php/itlt/article/view/25/13. Accessed on: August 27, 2018. (in Ukrainian).

[5] A.Y. Pylypchuk, "Reforming of education and informatization: main problems and approaches for their solution", Information Technologies and Learning Tools, № 1 (5), 2008. [online]. Available: https://journal.iitta.gov.ua/index.php/itlt/article/view/155/141. Accessed on: August 27, 2018. (in Ukrainian).

[6] V.V. Osadchyj, and K.P. Osadcha, "Modern realities and trends of information and communication technologies development in education", Information Technologies and Learning Tools, v. 48, № 4, p. 47-57, 2015. (in Ukrainian).

[7] T.I. Koval, ""Features of the introduction of distance learning technologies in higher education in the conditions of socio-economic transformations" in Allukrainian naukovo-practical conference "Osvitology is a scientific direction of integrated cognition of education", Kiev, 2010, pp. 54-58. (in Ukrainian).

[8] V.V. Oliinyk, Open postgraduate pedagogical education and distance learning in questions and answers. Kiev, Ukraine: "A.S.K", 2013. (in Ukrainian).

[9] K.L. Buhaichuk, " Blended learning: theoretical analysis and strategy of implementation in educational process of higher educational institutions", Information Technologies and Learning Tools, 2016, № 4 (54). [online]. Available: http://journal.iitta.gov.ua/index.php/itlt/article/view/1434. Accessed on: October $05,2018$.

[10] O.V. Karelina, "The formation of skills of information technologies in the process of distance learning of students of higher economic educational establishments", Avtoref. diss. cand. ped. sciences, Ternopil Volodymyr Hnatyuk National Pedagogical University, Ternopil, 2005. (in Ukrainian).

[11] K.P. Osadcha, and V.V. Osadchyj, Distance Learning Technologies. Work with Moodle 2.4, Melitopol, Ukraine: Vyd-vo MDPU im. B. Khmeljnycjkogho, 2014. (in Ukrainian).

[12] D.R. Garrison, and H. Kanuka, "Blended Learning: Uncovering Its Transformative Potential in Higher Education", Internet and Higher Education, 7 (2), 95-105, 2004. (in English).

[13] International Convention on Standards of Training, Certification and Watchkeeping for Seafarers 1978. [online]. Available: http://zakon0.rada.gov.ua/laws/show/995_053. Accessed on: October 05, 2018.

[14] Competencies. [online]. Available: https://docs.moodle.org/33/en/Competencies. Accessed on: August 26, 2018. (in English). 